\title{
World Population Day 2018: Family Planning is a Human Right
}

The population of the world is increasing at a rapid pace, and faster is the rate of depletion of resources. The human race is facing the constant challenge of providing adequate resources for the ever-increasing population of the world. To provide light on this important issue, I am grateful to the editorial staff of IHRJ for providing me an opportunity to write a guest comment on the important occasion of world population day.

It was in the year 1989 that this day was first celebrated on the $11^{\text {th }}$ of July with the aim to make every person on the globe aware of the population in various countries and its effects on the daily life on people. This date holds its significance as it was on this day that the world's population reached 5 billion and has been termed as "Five Billion Day". ${ }^{1}$ The theme chosen for the year 2018: "Family planning is a human right" is apt as per today's scenario as if the population explosion is not managed properly, in the times to come, there will an over-dependence on resources (both natural and man-made) on the already over-burdened mother earth.

It hurts me to state that the year 2018 marks the $50^{\text {th }}$ anniversary of the International Conference on Human Rights held in 1968. For the first time ever, family planning was affirmed to be a human right by adoption of the Tehran proclamation which states that it is a basic right of parents to be able to decide the number and spacing of their children. But alas, there still are millions of women who are still not given access to safe and effective family planning methods. There are also various conservative societies that do not want to adopt these family planning practices. Also, discussion of family planning methods is still considered as a taboo in many societies and hence, leads to an increase in the population globally.

Another factor to consider is women's right and their education. Women should be educated about the ill health consequences involved in multiple births. They should be made free to choose the family planning method without any hesitation. Moreover, the ill practice of child marriage followed even today, leads to increasing population day by day.

There is still a ray of hope in curbing the menace of population growth. Countries like Ukraine and Russia (o.8\% and $0.6 \%$ natural decrease annually) need to be appreciated for zero population growth percentages. ${ }^{2}$ On the other hand, the top four countries with the highest population: China, India, USA and Indonesia ${ }^{3}$ should constantly make efforts so that the projected population growth rate remains acceptable or even preferably negative in their respective countries.

The increase in population has already begun to show its effects on Mother Nature, forests and with them, wildlife is being depleted at a fast pace, pollution has reached at such unacceptable levels, that the air we breathe itself poses as a health hazard. Natural resources like oil and water are at the level of exhaustion. Similarly, the consumption of food has increased, and to sustain a constant supply shall become a herculean task for governments in the near future.

It is hence, advised that the issue of population explosion needs to be addressed with results. The governments should ensure that the womenfolk in their countries are educated, and families have constant access to family planning methods. It is then, that with these constant efforts over the next few decades, we shall be able to reduce the effects of an increased population and save out natural resources from depletion.

\section{REFERENCES}

1. https://www.awarenessdays.com/awareness-dayscalendar/world-population-day-2018/

2. https://internetworldstats.com/stats8.htm

3. http://www.worldometers.info/world-population Lpopulation-by-country/ 
Source of support: Nil, Conflict of interest: None declared

\section{Cite this article as:}

Sant A. World Population Day 2018: Family Planning is a Human Right. Int

Healthcare Res J 2018;2(4): 74-75. doi: 10.26440/IHRJ/02_04/177.

Author Details:

BDS (Private Practitioner)

\section{Correspondence Address:}

Dr. Ankita Sant

House No. 4448

Ranjitpura

Near Sikh Missionary College

\section{P.O. Khalsa College}

Puttigarh

Amritsar
For article enquiry/author contact details, e-mail at: manuscriptenquiry.ihrj@gmail.com 